\title{
Reconnecting Self-Organising Institutions to the formal Government Structure for Real Governance Impact in Nigeria
}

\author{
By \\ Samson R. Akinola, $\mathrm{PhD}^{1}$ and Ayo Adesopo, $\mathrm{PhD}^{2}$
}

\begin{abstract}
The crisis of democratization in Nigeria has its roots in the centralised planning, monocratic decision making and repressive institutional arrangements the country adopted at independence in 1960, which invariably lack a common thought between the assembly and the electorate. This is because indices of democracy and development have constantly eluded the electorate especially in the last ten years. Most socio-economic and political decisions in Nigeria did not reflect the wishes and aspirations of the poor simply because of the persistent and widening gaps between decision makers (the rich people) and the governed (the poor). Accordingly, the residents have learnt not to rely on governments, instead they have devised several coping strategies through self-organizing arrangements that draw inspirations from their culture and traditions. This paper critically examines how poor people craft shared strategies and problem solving interdependencies from their old traditions to address problems of daily life by providing and maintaining infrastructure such as schools, health facilities, road networks etc. At the same time, the tenets of democracy exhibited by these self-governing institutions as well as their contributions to socio-economic development have made them highly relevant to governance of community affairs. This paper, therefore, suggests polycentric planning and institutional arrangements capable of mainstreaming or reconnecting these self-organising or peoplecentred institutions into socio-economic and political decision making so that the poor in Nigeria can participate effectively in decisions that concern their lives, thus entrenching self-governance in Nigeria's democratisation project. It is in the light of this exigency that this paper adopts African Public Sphere Restructuring Model (APSRM) that could help in restructuring the public sphere for synergy and African Electoral Reform and Democratisation (AERD) for inclusive democratisation.
\end{abstract}

Key Words: Democracy, Government structure, Self-governing institutions, Polycentric Planning

\section{Introduction}

African states are more highly centralized than most of the other world's regions. This highly centralized African state has tended to become a part of the problem rather than be a part of the solution. It is inefficient, corrupt and ineffective in providing 
access to basic services. It has failed to mobilize the high levels of social capital for improved development or governance. It is poorly incapacitated and sluggish in providing the environment for economic growth and poverty reduction (Olowu, 2006:7). It has been observed that the most devastating cause of poverty is bad governance, which is also traced to the system of administration adopted during the colonial and post-colonial era. The system was(is) democratically centralized, too regimented for humans as it limits citizens' freedom in making contribution towards decision making in community affairs, human development and civilization. It is boss rule, command and control, and autocratic. It separates leaders from their people. Bad governance is rooted in culture as much as in structure. While poverty is often discussed from the point of view of economic disabilities, it is becoming clearer that Africa's poverty is rooted fundamentally in its culture of politics-the impoverishment and disempowerment of the people of Africa by African leaders and a structure of power which ensures that oppressors misrule with impunity, while those oppressed have limited or no opportunity to resist their oppressors.

As a matter of fact, no appreciable progress has been made in spite of all the efforts of some African leaders and international donors on African countries. This provides explanation for the failure of series of Declarations and Resolutions made by African leaders over the last four decades (from Algier's Summit, 1968; The Kinshasa Declarations, 1976; The Moronvia Strategy, 1979; Lagos Plan of Action, 1981 to NEPAD, 2001) to address persistent socio-economic and political crises in the continent. The state-dominated and state-driven economy has no mechanism and inspiration to rally the large percentage of African citizenry, who are in the informal sector around socio-economic and political projects. For example, over the past four decades, from 1975 to 2001 (a period of 26 years), a total of 28 different reforms and programmes with poverty alleviation thrust (NEEDS, March 2004 Edition, pp. 153-156) that cut across socio-political economy have been carried out by the Federal government of Nigeria, yet the economy has been stagnant, perpetuating inequality of social conditions among the people of Nigeria (Akinola, 2005, 2005b).

The state-dominated and state-driven economy has no mechanism and inspiration to rally the large percentage of the citizenry, who are in the informal sector around socioeconomic and political projects. Consequently, most socio-economic and political decisions did not reflect the wishes and aspirations of the poor simply because of the persistent and widening gap between decision makers (the rich people) and the governed (the poor). Infrastructures that are incentives for entrepreneurial development and nerves of the economy are increasingly deteriorating. Consequently, three category of poverty emerged: poverty of money; poverty of access to services (water, electricity, waste disposal, roads, security etc); and poverty of power.

Over the years, Nigerian governments have implemented several programmes that could address poverty but such programmes were not people-oriented. The programmes are divided into two: (a) poverty reduction programmes in rural area to reduce rural-urban drift, and (b) poverty reduction programmes that cut across both rural and urban areas.

Due to the gap between Nigerian leaders and the people on the one hand, and the problem of corruption that had eaten deep into the leadership on the other hand, the programmes implemented by the Nigerian governments have ended in enriching the 
pockets of few people at the corridor of power. These programmes, no doubt, injected a lot of money into "circulation" but are concentrated in few hands at the corridor of power. For example, the top $20 \%$ of the population in Nigeria owns $94.6 \%$ of the wealth in the country, while the bottom $60 \%$ owns 3.5\% (Nigerian National Living Standard Survey, 2006). The consequence of this is inflation which further pushes up prices of basic needs of life outside the reach of the people. In essence, government's intention of addressing poverty has, however, due to bad governance, made poverty to loom large among the majority of Nigerians. In spite of the increase in growth rate of the economy $\{(7.8 \%$ in 2010 which was significantly higher than the global average of 3.9\% (Manuaka, 2011:35)\}, the welfare of the citizenry has plummeted - "jobless growth and paper growth" - rising economic growth is inconsistent with rising food shortage, poverty ${ }^{1}$ and rising unemployment (Akinola, 2007a; CDD, 2013). The governance styles of Nigerian leaders, both during the military and civilian regimes, have perpetuated poverty with dualistic policy in all sectors of the economy - housing, transport, health, education and other essential services.

This paper analyses constituency projects embarked upon by some lawmakers and at the same time discusses diverse ways in which citizens organize themselves and address challenges and problems of daily existence. In order to make the nascent democracy deliver to the electorates, the federal government considered it imperative to use lawmakers (being that they are very close to the grassroots) as one of the means of injecting development into their constituencies. Unfortunately, from decision making, project implementation and conditions of constituency projects of the lawmakers were a charade. The projects constituted conduit pipes by which lawmakers siphoned money meant for the grassroots development. The failure of these and such other projects have led the citizens to devise several coping strategies through self-organizing arrangements that rely on inspirations of people-oriented institutions such as community development associations, occupational groups, women associations, religious groups etc. These groups, to an extent, have provided and produced infrastructure such as schools, health facilities, and road networks for their well-being.

This paper, therefore, suggests institutional arrangements on how to mainstream the selfgoverning institutions using polycentric planning by bringing the less-privileged into the mainstream of socio-economic and political decisions thereby synergizing the efforts of the state and the civil societies in a democratic manner. Polycentric planning is a deliberate act of setting up multilayered and multicentred institutional mechanisms that regard self-governing capabilities of local communities as foundation for reconstituting order from the bottom up. It can also be described as the process of ordering the use of physical, human and institutional resources as well as engaging the citizens in contractual

\footnotetext{
${ }^{1}$ Nigeria is a country of paradox with widespread poverty in the midst of plenty with high levels of poverty affecting over one hundred million Nigerians and low access to social services. Nigeria is the largest oil producer in Africa and the seventh largest in the world, and yet the country has the third largest number of poor people in the world after China and India. While China and India have taken giant steps to tackle poverty and promote inclusive growth leading to a reduction in the number and proportion of poor people in the last decade, Nigeria has seen a significant rise of the absolute number of poor people in spite of impressive economic growth rates. Economic growth has not been impacting on the drive to reduce poverty as shown by statistics from the National Bureau of Statistics (NBS) (CDD, 2013).
} 
relations with the public authority (Akinola, 2009a, 2010, 2011). Consequently, this paper adopts African Public Sphere Restructuring Model (APSRM) that could help in restructuring the public sphere for synergy and African Electoral Reform and Democratisation (AERD) for inclusive democratisation.

The paper is divided into six sections. The paper is introduced in section one, while poverty and poverty alleviation in Nigeria is discussed in section two. The third section presents the theoretical framework on which the paper is anchored. The fourth section looks at self-organising institutions in the light of service delivery by highlighting their performance in selected areas. The fifth section covers the task of reconnecting selforganising institutions to the formal government structure through polycentric planning. The sixth section contains the conclusion.

\section{Poverty And Poverty Alleviation Programmes in Nigeria}

The definition of poverty is nebulous and elusive because poverty is multidimensional. However, Muzaali (1987) and UNDP (1999) define absolute poverty as human deprivation, a physiological phenomenon, in which an individual is totally unable to provide for his physical subsistence to the extent of being incapable of protecting his human dignity due to lack of access to remunerating work, food, clothing, shelter, portable water, health service, basic education and efficient transport system. Because of the meager income of such individuals, their marginal propensity to save is zero and their lives are short and brutish.

Relative poverty, on the other hand, is the inability on the part of certain sections of the society to satisfy their basic needs compare with others who are better off (OseiHwedie, 1993). The relative concept, therefore, is based on the notions of inequality and distributive justice (equity and power relations). This is because of the assumption that the poor also must enjoy some of the existing consumption patterns and life styles in the society. It may be measured as a fraction of the distribution of income.

The difficulty encountered in defining, classifying and measuring poverty made Dannito and Dyte (1983) come up with four approaches namely: deprivation, inequality, culture and exploitation. In a like manner, Soyombo (1987) identified three approaches through which poverty can be defined. They are the subjective, statistical and relative or poverty line approaches. According to Mabogunje (1999), poverty can be defined in relation to four defining vectors in the matrix of individual life chances. These are the economic, the social, the environmental and the governance vectors. Against such matrix, it is easy to appreciate why poverty is regarded as multi-dimensional in the sense that, it is the deprivation of these four elements that makes one to be regarded as being poor.

It is pertinent at this juncture to point out that there are as many indicators of poverty as are human activities \{see for instance, Olowu and Akinola (1995)\}. On the basis of causative factors, poverty has been classified into two types: primary and secondary (Rowntree, 1901). Primary poverty arises when the income of an individual or family is insufficient to provide for the basic needs. It has also been described as deprivation, when leaders in a society fail to provide the basic facilities and services conducive for citizens' productivity. Secondary poverty arises from mismanagement of one's income that would otherwise have been sufficient for the satisfaction of one's basic needs. Fitted 
into the secondary group are those who are poor because of laziness and this group has been described as 'deserving group'.

In behavioral analysis the poor are grouped into three: transitional, marginal and residual poor (Segalman and Basu, 1981). The transitional poor are those struggling to get out of poverty if basic services that constitute incentives within an environment are made available. The marginal poor are satisfied with their subsistence condition, while the residual are those that depend on others - government and/or relatives - for survival.

Nigerian governments have implemented several programmes that were geared towards poverty alleviation between 1960 and 1986. Notable among them were Free and Compulsory Primary Education, Adult and Mass Literacy Scheme, Rural Electrification Scheme, Rural Banking Scheme, Operation Feed the Nation (OFN), Green Revolution, River Basin Water supply Scheme, Small Scale Enterprises Scheme with the associated credit programmes for their operators (Ekong, 1996). According to Ekong, there were also some poverty focused programmes between 1986 and 1993 and they were: National Directorate of Employment (NDE), Directorate of Food, Roads, and Rural Infrastructures (DFRRI) and Better Life Programmes (later replaced by Family Support Programme), Peoples Bank of Nigeria (PBN), Community Bank (CB), National Economic Reconstruction Fund (NERFUND), Family Economic Advancement Program (FEAP), etc. Other poverty alleviation efforts of government since 1996 were in agricultural sector where programmes like Agricultural Development Programmes (ADP), National Agricultural Land Development Authority (NALDA), Strategic Gains Reserve, Accelerated Crop Production Schemes, (ACPS), Development of Artisan Fishery and Small Ruminant Production, Pasture and Grazing Scheme were instituted.

From 2001 till date, the Federal Government of Nigeria launched several programmes such as The Petroleum (special) Trust Fund (PTF), and National Poverty Eradication Programme (NAPEP) to intervene in the critical areas of the need of the poor. NAPEP initiated some projects, programmes and schemes which are targeted at the core poor that need to be encouraged to participate in the economic development process. These include: The Mandatory Attachment Programme (MAP - 2001), The Capacity Acquisition Programme (CAP - 2001), Capacity Acquisition Programme (2004), The Multi-Partner Matching Fund Scheme (MP-MF), The Promise Keeper Programme (PKP), Revolving Micro Finance Scheme, The Social Safety Nets Intervention Scheme the Conditional Cash Transfer Programme (CCT), The Keke NAPEP Project (I\&II), The Farmers Empowerment Programme (FEP I\&II), The Community Economic Sensitization Scheme (COMESS), the Village Solution Scheme, etc.

Akinola (2012) observed that lack of coordination among various ministries and agencies saddled with the responsibility of addressing the problem of poverty has accounted for the failure of governmental efforts in poverty alleviation. Another factor that accounted for the failure of these programs is high level corruption. Corruption-induced poverty is, therefore, not only an outcome of economic processes but a product of economic, social and political forces. 


\section{Theoretical Framework}

This work is anchored on Public Choice Theory (PCT) as the theory recognizes the fundamental defects in the centralist model of governance and the persistence failure of the state to meet the collective yearnings and aspirations of the citizenry. Vincent Ostrom, having recognized the problems imbedded in Orthodox Public Administration, used the theory of Public Goods to reinvent a theory of democratic administration, which is gaining currency in the literature of Public Administration. This has been found useful by the Public Choice scholars in the development of an alternative institutional paradigm by calling attention to the self-governing and self-organizing capabilities of the people. Though this alternative paradigm was originally conceived within the context of American experience, it has become a potent alternative effectively employed by some African scholars in their works (Ayittez 1991; Olowu 1999, 2006; Olowu and Erero 1997; Ayo 2000, 2002; Sawyer 2005; Akinola 2004, 2005a, 2007, 2007a, 2008, 2009, 2009a, 2010, 2011, 2012, 2013). These scholars have confirmed the resilience and effectiveness of institutions designed and managed by the people. Those community institutions are found to have performed better than state-run institutions, and that community-based institutional arrangements readily meet the yearnings and aspirations of the people in delivering goals and services which the state-run institutions have failed to deliver efficiently and effectively (Akinola and Adesopo, 2014).

In view of this, the Public Choice Scholars have consistently advocated "deemphasizing the state as the sole focus of political theory and policy analysis" (Ayo, 2000:23), maintaining the position that effective governance and meaningful socioeconomic development can best be attained in human societies through systems of democratic administration. The main thrust of democratic administration is the people and a people-managed system of governance usually based on the principle that every individual is eligible to participate in the conduct of public affairs. This is opposed to the monocentric system of bureaucratic administration, which has one centre of authority. A system of democratic administration is characterized by a system of polycentricity, which empowers the citizens to organize self-governing institutions, nested within one another (Wunsch and Olowu, 1995:2). The Monocratic assumptions of Max Weber were intensely challenged by Alexis de Tocqueville's study of Democracy in America. The study brought to light the resilience and effectiveness of democratic administration characterized by polycentricity (Vincent Ostrom, 1974:69). A polycentric approach offers opportunities for institutional choices among a given group of people. The success and sustainability of the self-organizing capabilities of local communities are nurtured by polycentric governance (McGinnis, 1999:2). According to Elinor Ostrom (1992:16), self-governing system is a pre-requisite for sustainable development.

In view of the crises of governance attributable to the failure of centralized authority, scholars have recommended a paradigmatic shift from the centralist model to that of "self-governance" in solving problems emanating from the adoption of centralist model of governance. It is on this basis that a new school of thought has emerged and is fast gaining currency. Self-governance empowers citizens, protects individual choice and allows for polycentric institutional arrangement. It permits citizens to join with one another to take collective action (Wunsch and Olowu, 1995:274). 
Several experiments in local self-governance were embarked upon in the early 1950s across Africa. The most important contribution of these institutions was their remarkable success at building basic infrastructure - roads, clinics, bridges, markets, parks, water supply, forestry, agricultural extension, and police. Within the few years in which they were allowed to operate, they not only performed creditably but also most of these services were financed from locally generated revenue sources (Hicks, 1961).

Shortly after independence, however, the pendulum swung to the other extreme as postcolonial African political elites conceived the state as the prime mover of development (Edigheji, 2004:92). The ruling elite did not encourage the development of the private sector as the latter was treated with suspicion. Consequently, the post-independent African state is unable to articulate a transforming project or mobilize society around such a project, it is not equipped to respond to the needs and aspirations of African people. As a result, poverty looms large among the citizenry.

Considering the two methods of classification of poverty - causal and behavioral methods, most of the poor in Nigeria fall into the primary poverty group (for causal) and transitional poor (for behavioral) for some reasons. Infrastructures built in the 1960s and 1970s that served as incentives for entrepreneurial development and nerves of economy started deteriorating in the 1980s at an increasing rate. Consequently, several reforms on poverty alleviation adopted by successful governments (military and civilian) failed woefully to increase the standard of living of the majority of the Nigerian people.

Poverty of power is yet another which is people's lack of political right to make input into decision that concerns their lives. Without power or political right there is no voice in decision making on societal affairs which may be disadvantageous to individuals in terms of service delivery. Olomola (2003) also corroborates this assertion by describing poverty of power as political poverty. However, we disagree with Olomola's (2003) thesis that Nigerians are poor because of their strong apathy towards voting and participation. The reason is simply that there have been no institutional mechanisms derived from integrative constitution order that could empower the people of Nigeria to participate in socio-economic and political decisions. As long as this is lacking, the people cannot participate. It is the prevailing constitution order in any society that is constitutive of a proxy for political economy. If the prevailing constitution order is repressive as we have in Nigeria, the poor people are marginalized and sidelined. Therefore, the present institutional arrangements can be said to have largely excluded the people of Nigeria in their diverse ecological settings.

There is a serious problem of disconnect in Nigeria that has accounted for the failure of the series of reforms, strategies and poverty alleviation programmes implemented in the country. For example, the Nigerian growth rate in 2010 was 7.8\% (Manuaka, 2011:35) significantly higher than the global average of $3.9 \%$. But this has not translated into an improvement in the welfare of the people - "jobless growth and paper growth" - rising economic growth is inconsistent with rising poverty ${ }^{2}$ and rising unemployment (CDD,

\footnotetext{
2 Nigeria is a country of paradox with widespread poverty in the midst of plenty with high levels of poverty affecting over one hundred million Nigerians and low access to social services. Nigeria is the largest oil producer in Africa and the seventh largest in the world, and yet the country has the third largest number of poor people in the world after China and India. While China and India have taken giant steps to tackle poverty and promote inclusive growth leading to a reduction in the number and proportion of poor people
} 
2013). Unemployment has increased to $23.9 \%$ as at November 2011, as against 21 per cent in 2010 (Sawyerr, 2012). How do we reconcile this growth with a situation where Nigeria is spending 1.0 Billion daily on the importation of rice (Akpeji and Ajayi, 2012) when there are several agricultural innovations, abundant lands and water bodies with teeming and virile youth, majority of who are graduates roaming the streets in search of jobs? These factors constitute indicator of governance deficit, underdevelopment and poverty.

In spite of the failure of the Nigerian government in the area of poverty alleviation programmes, Nigerian people have resorted to trusted institutional arrangement by building confidence and trust in one another. As we have been reminded by Olowu and Wunsch (2004), the people in a community collectively decide to create a new organizational structure for the common good to deal with matters that they cannot address via existing mechanisms. Similarly, Elinor Ostrom and others have discovered that Hardin's "villager"3 has survived through a multitude of ingenious strategies using local governing systems. These community-based approaches have shown that it is possible to share the fruits of the commons without destroying them (Hickel, 2002:27).

It is important to note that the economic, social and political impacts of these institutions are being rediscovered, especially in developing countries (Narayan et. al. 2001). There is evidence that civil society - i.e. occupational, community-based, and religious organizations - exists at localities all over Africa, and in some circumstances can be an important participant in service delivery and in enforcing accountability (Olowu, Ayo and Akande, 1991; Barkan, 1994; Dia, 1996; Olowu and Erero, 1997; Adedeji and Otite, 1997; Coulibally, 1999; Ribot, 2000, Akinola, 2000, 2003, 2004, 2005a, 2006, 2008b, 2009, 2009a, 2010, 2010a).

However, Olowu and Wunsch (2004:248) noted that though these community institutions and social capital exist in many African countries, only few countries succeeded in connecting them to the local government system. This aspect of "lack of connection" is critical and should be a source of serious concern for policy consideration in Nigerian governance structure. If these institutions are viable (though not perfect), the question then is how do we connect them to the formal government structure?

\section{Self-Organising Institutions and Service Delivery in Nigeria}

The poor have no confidence in those who run Nigerian government, hence they invest their sovereignty horizontally in one another through collective action and self-organizing capabilities and thereby, to an extent, addressing local challenges -

in the last decade, Nigeria has seen a significant rise of the absolute number of poor people in spite of impressive economic growth rates. Economic growth has not been impacting on our drive to reduce poverty as shown by statistics from the National Bureau of Statistics (NBS) (CDD, 2013).

${ }^{3}$ Hardin, Garret explained in The Tragedy of the Commons, the conflict of freedom and the common ownership of a resource. He described that each villager has freedom to graze his cattle, knowing that any additional animals he adds will bring him greater benefit in spite of the degradation of the range. Hardin wrote, "Each man is locked into a system that compels him to increase his herd without limit - in a world that is limited. Ruin is the destination toward which all men rush. Freedom in a commons brings ruin to all (Hardin, Garret 1968:4). 
education, health, community hall, postal service, security services, road repairs and other essential services. Their decisions are premised on two grounds. First, whether they vote or not election results are determined and manipulated by 'god-fatherism', money-bag politics, and violent politics. Second, the public space is restricted to the few elite and their cronies; thus having the liberty for pillage and plundering since they are not accountable to the people.

The people in Nigeria collectively decide to create a new organizational structure for the common good to deal with matters that they cannot address via existing mechanisms. In the process they voluntarily transfer to the new entity the right and authority to exercise direction and control over the actions of specific individuals in specific areas of communal life, as well as to require compliance of the general community in financing operations.

\subsection{Highlighting the Performance of Self-Organising Institutions in Nigeria 4.1.1 The Performance of Self-Governing Institutions in Yorubaland}

The study of community development since 1990 across Yorubaland confirmed that community-based institutions, though not perfect, have been very robust in the way they conduct community affairs and render essential services to the people at the grassroots. Data discussed in this section were derived from 51 community-based institutions (CBIs) across Yorubaland.

In 1959 when the Nigerian government had only 11 primary schools, four secondary schools, a technical institute, a trade center and two teacher training colleges, voluntary agencies owned and managed 4,841 schools (Eastern Nigeria Ministry of Education, 1962:38; Nwafor, 2002:211). Twelve of fifteen primary schools in Gbongan and its environs were owned by religious and private organizations, while only three were established by government. At Oke-Igbo, only one primary school belonged to the Local Authority; there are other five primary schools that were established by religious organizations in the town. Between September 1976 and December 1979 the impact of Community Development activities in the Akinyele Local Government in Oyo State has been tremendous - 44 road projects, two dispensaries, three maternity centers, 12 wells, a community hall and four markets have been completed (Gboyega, 1980:126).

The level of State Government and Local Government support for community social welfare activities leave much to be desired. According to Gboyega (1980:127), prior to 1971, Local Governments in the Western State did not budget at all for community social welfare activities; and in that year (1971), of councils' total expenditure of $\$ 4,015,629$ only $\$ 21,243$ (a derisory $0.53 \%$ ) went for "Community Development and Social Welfare." The State Governments' support has been little better. Between $1970 / 71$ and 1972/73 fiscal years there were 1,459 projects in the western state and the State Government's grant was only $\$ 290,000$. Similarly, between 1973/74 and 1974/75 the estimated cost of community projects was $23,028,703$ and Government grants amounted to $\$ 891,690$ (3.9\%). In 1978/79 Councils in Oyo State budgeted $\$ 86,835$ $(0.13 \%)$ out of total estimated expenditure of $\$ 65,526,849$ for community development. The implications of the trend reported above are clear. For one thing, if local communities have to rely so predominantly on their efforts for social services, why should they pay taxes to their local authorities? 
Findings from Igboho in Oke-Ogun area of Oyo State in 1990 shows that members of Ifelodun Omo Igboho community association provided and produced several goods and services for their community: Igboho-Igbeti earth road - 44 kilometers (1950), Igboho-Ogbooro earth road (1954), dispensary (1954), police post (1955), postal agency (1956), town hall (1959), Baptist secondary modern school (1960), motor park (1960), Owode market - 20 open stalls - (1961), Igboho-Agbonle road (1962), Irepo Grammar School Science block (1967), slaughter slab (1976), ultra-modern post office (1978), Igboho-More Community Grammar School (1979), Ifelodun Grammar School (1981), conversion of Baptist Modern School to Baptist High School (1982), Post Office (1984), secretariat renovation (1989) (Akinola, 1991). In this community there was no single project provided by government within the period of 38 years (1950-1988). For instance, Igboho which was the headquarters of Ifelodun Omo Igboho Association was developed through the efforts of the people, got transformed and now the headquarters of Orelope Local Government in Oyo state.

In 1999, a survey conducted in Olaleye and Iponri communities, Lagos Mainland local government area (LGA) showed that the projects embarked upon by the institutions, no doubt, have increased the level of access of the people to infrastructure facilities. The two communities spent $\$ 615,000.00$ on socio-economic projects between 1983 and 1997, while some $455,000.00$ was contributed towards the same projects by government, World Bank and other international donors. Thus, community development efforts constituted the prime mover $(60 \%)$ of the community development (Akinola and Akutson, 2001).

Similarly, Akinola (2000:182) shows that the contribution of community development associations $(87.7 \%)$ is far greater than that of the Local Governments $(12.3 \%)$ in four states of southern Nigeria. Indication from another study points to the fact that the role of community development associations is all-embracing. The Community Development Association in Odigbo, Odigbo LG, Ondo state under the umbrella of self-help cum cooperative housing has provided housing facilities for not less than $75 \%$ of members of the association. With 120 members, the group has provided not less than 90 houses for its members (Akinola, 2000:182).

Analysis of data from twelve of 31 CDAs in 10 wards of Egbeda LGA in Ibadan, Oyo State in 2001 shows that the CDAs in the LG contributed the lion share $(92 \%)$ towards the provision, delivery and maintenance of community services, while the LG that is constitutionally empowered and supported with resources spent only $8 \%$ towards the same endeavours (Akinola, 2004:56).

Another set of data on the contributions of community-based institutions in Ede community, Osun State; Emure community, Ekiti State; and Iloti community in Ijebu Ode, Ogun State between 2003 and 2005 confirmed the resilience of community-based and people oriented institutions at the grassroots (see Table 1). 
Table 1: Summary of Community Projects in Ede, Emure and Iloti Communities in Yorubaland

\begin{tabular}{|c|c|c|c|c|}
\hline $\mathbf{S} / \mathbf{N}$ & $\begin{array}{l}\text { Self-Governing } \\
\text { Institution }\end{array}$ & Projects Executed & $\begin{array}{l}\text { Contribution by } \\
\text { SGI }\end{array}$ & $\begin{array}{l}\text { Contribution } \\
\text { by LG }\end{array}$ \\
\hline 1 & $\begin{array}{l}\text { SGIs in Ede LG, Osun } \\
\text { State }\end{array}$ & $\begin{array}{l}\text { Roads, } \quad \text { Electricity, } \\
\text { Education, } \quad \text { Market, } \\
\text { Palace, Community Hall }\end{array}$ & $\begin{array}{l}\sharp 8.152 \text { Million } \\
\text { plus } £ 688\end{array}$ & $\begin{array}{l}\text { Million } \\
\text { plus } £ 250\end{array}$ \\
\hline 2 & $\begin{array}{l}\text { SGIs in Emure LG, } \\
\text { Ekiti State }\end{array}$ & $\begin{array}{l}\text { Shopping } \\
\text { Complex, } \\
\text { Hospital, } \\
\text { Palace }\end{array}$ & 61.9 million & 6.9 million \\
\hline 3 & $\begin{array}{l}\text { SGIs in Iloti, Ijebu } \\
\text { Ode LG, Ogun State }\end{array}$ & $\begin{array}{l}\text { Water Supply, Roads, } \\
\text { Market, } \quad \text { Community } \\
\text { Hall, } \\
\text { Education, Health }\end{array}$ & $\$ 27.1$ million & $\$ 0.5$ million \\
\hline \multicolumn{3}{|c|}{ Total/Average } & $\begin{array}{l}\text { 97.152 million } \\
(92.8 \%) \text { plus } \\
£ 688(73.3 \%) \\
=\mathbf{8 3 . 1 \%}\end{array}$ & 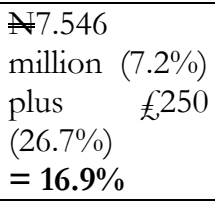 \\
\hline
\end{tabular}

Source: Survey, 2005 a.

According to data, Ede Descendant Union commenced community development operation since 1968 with market and educational facilities. As at 2003, the institution has spent $\$ 8.152$ million $(98.2 \%)$ and $£ 688$ (73.3\%), while the local government contributed $\$ 0.146$ million (1.8) and $£ 250(26.7 \%)$ on several socio-economic projects for the benefit of all community dwellers.

Emure CDA, through concerted efforts, initiated and embarked on some projects among which were: Elemure's Palace, Shopping Complex and Motor Park. Apart from Emure Model High School and General Hospital to which the World Bank contributed $\$ 44.32$ million (94.0\%) and the community generated $\$ 2.8$ million $(6.0 \%)$, the burden of other projects were borne by the community to the tune of $\$ 59.1$ million. It was only the Motor Park in the town that the LG provided at a cost of $\$ 6.9$ million.

Community development under the aegis of Iloti Federation Union in Ijebu Ode LG, Ogun state also attests to the immense capability of the people through collective action. With activities and projects ranging from bore-holes, market stall, electrification (three transformers), Community High School and Maternity Centre, the community spent $\$ 27.1$ million (98.2\%), while the LG assisted with $\$ 0.5$ million (1.8\%). The efforts of these institutions were borne out of the glaring 'neglect' of the community welfare by LGs. In sum, the amount spent by these three community-based institutions accounted for $83.1 \%$, while the figure for Local Governments was $16.9 \%$.

Similarly, religious organizations are not left behind in community development activities. Both the Christian and Islamic religions have provided and produced several community projects (covering the areas of health and education) in Saki, Oke-Ogun of Oyo State. The amount of money these religious institutions spent on social infrastructure was $\$ 2.1$ billion $(99.0 \%)$, while governments contributed $\$ 2.3$ million $(1.0 \%)$ towards the same projects (Akinola, ibid). 
The critical question is, in spite of allocations received by LGs from the federation account, where is the impact on the grassroots development? The question of local government as agent of grassroots development cannot be answered until there are effective checks on those who run Nigerian local governments by the electorates. Considering huge financial allocation received from the central government by Nigerian LGs without any tangible impact on the welfare of the people, it is therefore confirmed that the present structure makes these LGs to be irrelevant to grassroots development.

\subsubsection{The Performance of Self-Governing Institutions in the Niger-Delta Socio-economic Activities of Self-Governing Institutions}

Table 2: The Activities of Self-Governing Institutions (SGI) in Niger-Delta

\begin{tabular}{|c|c|c|c|c|c|}
\hline $\mathbf{S} / \mathbf{N}$ & $\begin{array}{l}\text { Self-Governing } \\
\text { Institution }\end{array}$ & $\begin{array}{l}\text { Projects } \\
\text { Executed }\end{array}$ & $\begin{array}{l}\text { Contribution } \\
\text { by SGI }\end{array}$ & $\begin{array}{l}\text { Contribution } \\
\text { by LG }\end{array}$ & $\begin{array}{l}\text { *Allocation } \\
\text { to LG (June } \\
2002)\end{array}$ \\
\hline 1 & $\begin{array}{l}\text { SGIs in Gokana } \\
\text { and Khana LGs, } \\
\text { Rivers State }\end{array}$ & $\begin{array}{l}\text { Roads, bridge, } \\
\text { water supply, } \\
\text { health, and market }\end{array}$ & $\begin{array}{l}\$ 35.3 \text { million } \\
\left(73.2^{\circ}\right)\end{array}$ & $\begin{array}{l}\$ 12.9 \text { million } \\
(26.8 \%)\end{array}$ & $\$ 29.9$ million \\
\hline 2 & $\begin{array}{l}\text { SGIs in Tai LG, } \\
\text { Rivers State }\end{array}$ & $\begin{array}{l}\text { Water supply, } \\
\text { health, bridge, and } \\
\text { market }\end{array}$ & $\begin{array}{l}\$ 21.8 \text { million } \\
(82.15 \%)\end{array}$ & $\begin{array}{l}\$ 4.1 \text { million } \\
(17.85 \%)\end{array}$ & $\$ 29.9$ million \\
\hline 3 & $\begin{array}{l}\text { SGIs in Yenegoa, } \\
\text { Sagbama, Brass } \\
\text { LGs etc. in } \\
\text { Bayelsa State }\end{array}$ & $\begin{array}{l}\text { Water supply, } \\
\text { bridge, transport, } \\
\text { education and } \\
\text { health }\end{array}$ & $\begin{array}{l}¥ 18.5 \text { million } \\
(82.2 \%)\end{array}$ & $\begin{array}{l}¥ 4.0 \text { million } \\
(17.8 \%)\end{array}$ & $\$ 32.9$ million \\
\hline 4 & $\begin{array}{l}\text { SGIs in Ilaje LG } \\
\text { in Ondo State }\end{array}$ & $\begin{array}{l}\text { Town hall, water, } \\
\text { transport, } \\
\text { education and } \\
\text { market }\end{array}$ & $\begin{array}{l}\$ 7.5 \text { million } \\
(70.0 \%)\end{array}$ & $\begin{array}{l}¥ 3.2 \text { million } \\
(30.0 \%)\end{array}$ & $\$ 30.1$ million \\
\hline \multicolumn{3}{|c|}{ Total/Average } & $\begin{array}{l}\$ 83.05 \\
(77.4 \%)\end{array}$ & $\begin{array}{l}\$ 24.21 \% \\
(22.6 \%)\end{array}$ & $\$ 30.7$ million \\
\hline
\end{tabular}

Source: Akinola 2008, p. 100.

$L G=$ Local Government

* = Average monthly allocation to each local government by the Federal Government.

In the Niger-Delta, a total of 21 community-based institutions were studied. Table 2 shows that the selected institutions, over the years, have initiated and provided public goods and services that worth over $\$ 83$ million, an amount that constituted $77.4 \%$ of $\$ 107.3$ million, the total cost of the projects. The Local Governments in the selected communities contributed $\$ 24.2$ million that accounts for $22.6 \%$ of the total money spent on the same projects. No doubt, self-organizing and self-governing institutions have impacted positively on the development of grassroots communities in the Niger Delta Area. Unfortunately, the Local Government which receives an average $\$ 30.7$ million per month (using the June 2002's figure) and $\$ 368$ million per year has done nothing in terms of service provision for the people at the grassroots in oil communities. From the above analyses, it is clear that mass mobilization strategy provides answers to most local development questions which the state has been dodging over the years. 
Rather than waiting for the local government authorities, that are closest to them (and with a lot of money), the communities in Yorubaland and the Niger-Delta through selforganizing and self-governing capabilities have planned and executed several public goods and services that directly touched the lives of their people. These groups see the need to come together and address their universal problems. It is only at this level of common pool resources that some achievements have been realized. This is the doctrine of polycentric governance which provides alternative strategies to address problems of daily existence at the grassroots level in the face of dismal performance of the modern state institutions.

In a related intellectual pursuits embarked upon by Olowu (1999:213), polycentric governance has been described as local self-governance which emphasizes three important attributes that are germane to democratic setting and which will invariably increase the level of public accountability. The attributes are: locality, primary accountability to the local people, and the provision of important regulatory, economic, or social services or a combination of all. The direction and control of the affairs of the local community by the people themselves is central to the concept of local self-governance. As matter of fact, the success story of these institutions cut across Nigeria, including the north and middle-belt regions (see for details, Akinola 2000:181-182).

The argument is that if Nigeria, as a developing nation, wants to emulate the successes of advanced industrial society, then she needs to learn how to make efficient use of her physical, human, and institutional resources. But the processes of learning need not be unidirectional. Experiences of community-based institutions in Nigeria on rule-rulerruled relationship in meeting common challenges in the delivery of common goods and social services, conflict resolution mechanism and protection of lives and properties need to be taken into consideration in policy formulation. There is need to understand the ways by which local communities manage those resources that are most important to their own survival or prosperity.

The results of all the case studies on the impacts of community-based institutions (CBIs) show that the level of participation by community members in their institutions was higher than local government. Many of the institutions write, approve and adopt constitutions that guide their activities. Unlike the local governments whose main laws and edicts are imposed on them more often by the federal and/or state governments, CBIs organize and direct their own affairs in response to the needs of the communities. Because the level of participation is high, more attention is paid to the enforcement of accountability than the local governments. These experiences are not limited to Nigeria alone; they are common in other African countries as well, especially in Ghana, Chad and Uganda. However, within the framework of the modern state, these highly vibrant organs are largely apolitical, and in some cases antipolitical. Both of these patterns are in large measure a reaction to years of anti-democratic environments in most African states (Davidson, 1992; Mamdani, 1996).

The lesson we can learn from these institutions is how they are able to mobilize and use resources judiciously. Contrary to this, local governments and other higher level of governments have access to greater resources that have left no significant impact on the lives of the people at the grassroots level. The concern is that if these institutions are so accountable to their members, we should begin to conceptualize how they could be used 
to re-constitute order from the bottom-up and to serve as alternatives to the statecentered institutions.

Analysis and discussions in this section show that in spite of the shortcoming of the state-centered institutions in Nigeria, Nigerians in various cultural and ecological conditions have attempted to address problems of daily existence through self-governing and self-organizing capabilities. This confirms that the people also govern and not to presume it is only government that governs. If the people govern, then government governs in a limited sense. In this respect, according to Olowu and Wunsch (2004:78), much might be made of community-level government and social capital, both to enhance "voice" and to improve local governance. It then becomes necessary for us to evolve and design appropriate institutional framework that will streamline the governing techniques of both the government and the people through polycentric planning.

\section{Reconnecting The Self-Organising Institutions Through Polycentric Planning in Nigeria}

In view of the fact that the genesis of poverty in Nigeria has been traced to lack of political power on the part of the people, solution lies in ensuring that political power is not concentrated in the hands of few elites but distributed among diverse individuals as persons and citizens. Therefore, in reconnecting the self-organising institutions, the first task is to restructure the public sphere such that the less-privileged can be brought into the main stream of democratic process through institutional framework capable of synergizing the elite and the non-elite to engage in open discussions on public affairs for productive outcome. The need for the adoption of this approach is further reinforced by the fact that the "professionals," no matter the degree of their expertise, cannot singlehandedly bring about changes in the life of the people except the people understand the basis and rational for these changes. If the rules are not understood by all as social orderings, institutions will most likely become ineffective (V. Ostrom 1971: 65-67) and probably set stages for destructive conflicts because few individuals that understand the rules are likely to exercise unlimited leadership prerogatives over some other groups of individuals and thus marginalize them since the former will always impose laws containing their own interpretations of order.

Any serious effort that will address poverty issues must therefore demand an adoption of polycentric planning and restructuring the public sphere in Nigeria. In the light of the above, this paper considers it imperative the adoption of African Public Sphere Restructuring Model (APSRM) (Akinola 2010, 2011). APSRM helps to restructure the public sphere in order to address the problem of "disconnect" in Nigeria, and then linking this to how people can work together, especially at community level, to address diverse challenges. APSRM is designed for the setting up of self-governing community assembly (SGCA) for deliberation, collegiality, mutual trust, reciprocity and shared community of understanding to enable citizens, both elite and non-elite, to operate in synergy to collectively achieve socio-economic and techno-political objectives (Akinola 2010:73-78, 2011:40-47, Akinola and Adesopo, 2014). Without a restructuring of the public space that could enable all the stakeholders and diverse interests to operate as 
colleagues with equal standing such that developmental benefits are shared equitably, developmental efforts will amount to a waste of resources and energy.

Similarly, African Electoral Reform and Democratisation (AERD) needs to be adopted for inclusive democratisation (Akinola 2008a:192-193, 2009a). AERD depends on African Polycentric Information Networking (APIN) that helps in establishing effective information networking. APIN serves as foundation for the formation of SelfGoverning Community Assembly (SGCA) where citizens, public officials and scholars can interact to: (a) design new institutional arrangements (b) formulate and implement people oriented policies (Akinola 2008a:188-189) and decide on how local resources are to be utilized and the benefit of economic growth shared equitably (Akinola 2010, 2013). The paper also considers it imperative to suggest the setting up of a system of checks and balances that characterised pre-colonial African political system and adopt it for citizens' enlightenment on socio-economic and techno-political affairs in Nigeria. That is why SGCA is composed of representatives of governments with their agencies, higher institutions, community institutions, occupational groups, women groups, youth, etc. Since SGCA is a multi-tasks assembly, one of its operations will have to do with education and enlightenment of citizens so that public officials and the people operate within shared communities of understanding.

Similarly, citizens should be prepared to engage in productive economic activities as they are made to open up through the operations of SGCA, especially in food security, employment generation and other development programmes. Local people along with local government managers should actively take on the challenge of engineering local economic development and at the same time explore the benefits of working at multiple scales, down to the neighborhood level, rather than only expecting governmental, national, and global solutions. Professionals who are indigenes (but reside outside their communities) need to be encouraged to come home and share their experiences with their people on project management and other issues of life that pertain to governance of community affairs. Both leaders and citizens need new orientations, which require some training at the level of SGCA.

The leaders need new orientation in community governance and management of community affairs. Leaders should come down to the level of citizens (as exemplified in African Electoral Reform and Democratisation model (ARED) ( - see Akinola 2008a:192-193; 2009a:98), while citizens need to be prepared for regular dialogues with their leaders. It is important at this juncture to point out that many citizens of Nigeria are ignorant of the fact that they have the civil rights to attend their local government meetings and that they have the right to questions about its revenue and expenditure. In the words of Aluko (2006:121), Nigerians and their African counterparts, even though they are aware of the corruption in their local government, prefer to "leave it to God" to judge the erring politicians. Invariably, citizens have concluded that corruption is an institutionalised way of life for public officers. This parochially institutionalized mentality should change and this can only happen through open dialogue at SGCA.

When citizens are able to realise and take full responsibilities in shaping and re-shaping socio-economic and techno-political configurations to suit their daily aspirations and yearnings through active and constructive interjections, then shared communities of understanding will be established. This will provide fertile ground for the adoption of 
successful practices elsewhere. Communication both in words and deeds between leaders and citizens should not be abstract; they should be in tangible forms - goods and services. The provision and quality of goods and services should form the basis for assessing politicians' performance by citizens.

The outcome of SGCA activities is the restructuring which is the emergence of new institutional arrangements, which would reflect integrative constitutional order in socioeconomic and techno-political realms. It is this joint action and synergy by all the groups (scholars, public officials, representatives of SGIs, CSOs, NGOs) that would eventually determine how government policies in all spheres of life are to be formulated and implemented. After the institutional arrangement has been designed, operational strategy for implementation of any programme/project (e.g. basic services, employment generation, food security, road development, poverty reduction, environmental management, electoral reform and democratisation, conflict detection, prevention and resolution, etc.) can then be fashioned out. It is at this stage that pragmatic and problemsolving home-grown models can be applied to any of the specific action situations (see such models in Akinola 2007a, 2008a, 2009a, 2010, 2011).

\section{Conclusion}

This paper establishes that the present institutional arrangements in Nigeria, invariably, skew democratic dividends towards the few elites that are involved in socioeconomic and political decisions, while the large majority of the people of Nigeria are sidelined. Having been disappointed by the Nigerian leaders over the years, diverse communities of individuals in Nigeria have learnt not to rely and trust those vested with leadership prerogatives. Consequently, the poor in diverse communities in Nigeria continue to explore pre-colonial governance heritage, invest their sovereignty horizontally in one another and through self-organizing and self-governing institutional arrangements have been able to accomplish the tasks of provision of public goods and services. The sort of open deliberation, accountability, patriotism and sanction against rule infractions that are inherent in these self-organizing and self-governing institutions and social capital are democratic values that should constitute the building blocks upon which viable democracy can be built in Nigeria.

Diverse associations and organizations the people in Nigeria have formed constitute the bedrock for implementation of polycentric order. Until the poor are brought into the main stream of decision making through appropriate polycentric arrangements, they can not be democratized and Nigerian democracy will continue to be illusionary, unrealistic, self-deceiving, self-defeating and tyrannical. In view of the requisite and inherent capabilities possessed by these self-governing institutions in providing and producing public goods and services, any attempt to neglect them as important democratic building blocks in Nigeria then constitutes a missed opportunity in the process of building a truly democratic and mutually productive ways of life. 


\section{References}

Adedeji, A. and O. Otite (ed.) (1997) Nigeria: Renewal from the Roots? The Struggle for Democratic Development. African Centre for Development and Strategic Studies (ACDESS), London and New Jersey: Zed Books.

Adejuyigbe, O. (ed.) (1980) Creation of States in Nigeria: A Review of Rationale, Demands and Problems up to 1980. Lagos, Federal Government Printers p. 53.

Adeniji-Adele, A. A. (1995): The Politics of Local Government in Lagos and its implications on the Urban Poverty and Urban Social structure: A real life experience" in Onibokun, A.G. and Faniran A. (eds): Government and Urban poverty in Anglophone Countries, West Africa. Centre for African Settlement Studies and Development (CASSAD), Monograph Series 4, pp. 187-198.

Akinola, S. R. (1991). "Self-help Projects and Rural Development: A Political Perspective", paper presented at the fourth national conference on political mobilisation for a stable third republic in Nigeria, organised by Faculty of the Social Sciences, Ondo State University, Ado- Ekiti, 9 - 11 December, 1991.

(2000): "Balancing the Equation of Governance at the Grassroots", in Adebayo Adedeji and Bamidele Ayo (eds.): People-Centred Democracy in Nigeria? The Search for Alternative Systems of Governance at the Grassroots, Ibadan: Heinemann Educational Books (Nigeria) Plc., pp. 171-197.

(2003) "Ensuring Public Accountability through Polycentric Governance Systems at the Local Level in Nigeria". In Emmanuel O. Ezeani (2003): Public Accountability in Nigeria: Perspectives and Issues, Academic Publishing Company, Enugu, Nigeria, pp. 379 - 395.

(2004): "Local Self-Governance as an Alternative to Predatory Local Governments in Nigeria", International Journal of Studies in Humanities (IJOSH), University of Nigeria, Nsukka, Vol. 3, No. 1, pp. 47-60.

(2005) "Economic Polycentricity and Partnership at the Local Level: A Strategy for Overcoming Food Insecurity and Poverty in Osun State, Nigeria". Paper presented at the First Economic Summit organized by the Osun State Government, MicCom Golf Hotels and Resort, Ada, Osun State, 25 - 26 April, 2005.

(2005a). "Structural Transformation and Polycentric Governance: Complementary Strategy towards Nigeria's Reform Agenda". Proceedings of the 14th General Assembly of Social Science Academy of Nigeria, Abuja, Nigeria, pp. 238-250.

(2005b) "Economic Polycentricity and Partnership at the Local Level: A Strategy for Overcoming Food Insecurity and Poverty in Irepodun Local Government Area, Osun State, Nigeria”. Paper presented at a Workshop organized by Morak and Associates for Local Government Managers and Representatives of Interest Groups in Irepodun Local Government Area, Osun State, October 6-7, 2005.

(2006) "Structural Transformation and Polycentric Governance: A Constitutional Gateway towards Nigerian Democratization". Paper presented at a Working Conference on 'Designing Constitutional Arrangements for Democratic Governance in Africa: Challenges and Possibilities', cosponsored by the Workshop in Political Theory and Policy Analysis, African Studies Program, and Office of International Programs, Indiana University, Bloomington, USA, March 30-31, 2006. (2007) "Coping with Infrastructural Deprivation through Collective Action among Rural People in Nigeria." Nordic Journal of African Studies. Vol. 16(1) 2007, pp. 30-46. (Online http://www.njas.helsinki.fi).

(2007a). Knowledge Generation, Political Actions and African Development: A Polycentric Approach. International Journal of African Renaissance Studies, 2(2):217-238.

(2008). Coping With Social Deprivation through Self-Governing Institutions in Oil Communities of Nigeria. Africa Today 55(1):89-107.

(2008a). "Alternative Planning Models for Development in Africa." In Knowledge to Remobilise Africa. ed. The Development Bank of South Africa, Johannesburg: Knowledge Management Division, pp. 169-202.

(2009). "The Failure of Central Policing and the Resilience of Community-Based Security Institutions in Nigeria." In Adekunle Amuwo, Hippolyt A.S. Pul and Irene Omolola Adadevoh, Civil Society, Governance and Regional Integration in Africa. Development Policy Management Forum (DPMF), Nairobi, Kenya, pp. 257-274. 
(2009a). "Polycentric Planning and Community Self-Governance as Panacea to the Niger Delta Crisis." African Journal of Development (AJD). New York University, USA, Vol. 11, No. 2, pp. 79-104.

(2010). "Restructuring the Public Sphere for Social Order in the Niger Delta through Polycentric Planning: What Lessons For Africa?" Journal of African Asian Studies, Vol. 9, Nos. 1-2. Cornell University, Ithaca, NY, USA, pp. 55-82.

(2011) "Restructuring the Public Sphere for Democratic Governance and Development in Africa: The Polycentric Planning Approach.” In Abdalla Bujra (ed.). Political Culture, Governance and the State in Africa. Development Policy Management Forum (DPMF), Nairobi, Kenya, pp. 1-61.

(2012). Overcoming Infrastructural Deprivation through Collective Action: A Study among Rural People in Nigeria. LAP LAMBERT Academic Publishing GmbH \& Co. KG, Dudweiler Landstraße 99, 66123 Saarbrücken, Germany, ISBN: 978-3-8465-5894-2, 303p.

and Z. Akutson, (2001) "Community Participation in Urban Poverty Reduction: A Case Study of Olaleye-Iponri Community in Lagos Mainland Local Government Area, Lagos State”. Paper presented at the $10^{\text {th }}$ Annual Conference of Population Association of Nigeria (PAN), University of Lagos, 14-17 October, 2001.

, M. B. Gasu, D. S. Ogundahunsi \& T. I. Ojo (2013). "Human Rights, Food and Employment Crises in Africa: Defusing the 'Time-Bomb' through Polycentric Planning and Poverty Reduction Strategy." Paper accepted for presentation at the African Regional Conference on Sustainable Development: Perspectives on Developing \& Sustaining the African Economy. Organized by African Research Council on Sustainable Development and the University of Ghana Business School at R. S. Amegashie Auditorium, University of Ghana Business School, Legon, Wednesday $24^{\text {th }}-$ Saturday $27^{\text {th }}$ July, 2013.

(2013). "The Logic of Planning Process and Security Challenges in Nigeria: A Polycentric Planning and Poverty Reduction Strategy (PPPRS)." Proceedings of the 44th Annual Conference of the Nigerian Institute of Town Planners (NITP), held at Concorde Hotels and Casino Ltd. Owerri, Imo State, Nigeria, $5^{\text {th }}-9^{\text {th }}$ November, 2013, pp. 45-88.

and Ayo Adesopo (2014) "Human Rights and Human Development Nexus in Africa: A Polycentric Planning and Poverty Reduction Perspective" in Advance Topics in Social Science and Humanity Research. New York: IISTE

Akpeji, Charles and Ajayi, Itunu (2012) "Government to stop $\$ 1.0$ Billion daily Spending on Rice Importation." The Guardian, Lagos, Tuesday, July 3, 2012, p. 7.

Aluko, Jones Oluwole (2006). Corruption in the Local Government System in Nigeria. Ibadan: BookBuilders.

Ayittez, G. B. N. (1991). Indigenous African institutions. New York: Transnational Publishers.

Ayo, S.B. (2000): Retbinking The Study of Nigerian Public Administration, Inaugural Lecture Series 140, Obafemi Awolowo University Press Ltd., Ile-Ife.

(2002). Public Administration and the Conduct of Community Affairs Among the Yoruba in Nigeria. Workshop in Political Theory and Policy Analysis, Indiana University, Bloomington, Indiana, Institute for Contemporary Studies, Oakland, California.

CBN (Central Bank of Nigeria) (1997): A Profile of the Nigerian Educational System and Policy Options for Improved Educational Development for Rapid Economic Growth and Development, pp. 26 - 27, 52.

CDD, (2013). "Creating Traction for Scaling up the MDGs and Poverty Reduction in Nigeria." Centre for Democracy and Development, Abuja, Nigeria. http://usmg5.mail.yahoo.com/neo/launch?.rand=dhvdst2ij8vso\#mail (Accessed 15/10/2013).

Coulibally, C. (1999) "On subsidiary in West Africa: A Contribution to Institutional Problem Solving in Africa." A paper presented at the Workshop 2 Conference, Workshop in Political Theory and Policy Analysis, Indiana University, Bloomington, Indiana.

Dannito, D.M. and Dye, T.R. (1983). Social Welfare: Politics and Public Policy, Engleword cliffs, New Jersey: Prentice Hall.

Davidson, B. (1992) The Black Man's Burden: Africa and the Curse of the Nation State, New York, Times Books.

Dia, M. (1996) Africa's Management in the 1990s and Beyond: Reconciling Indigenous and Transplanted Institutions. Washington, D. C.: World Bank.

Eastern Nigeria Ministry of Education (1962). Report on the Review of the Education System in Eastern Nigeria, Official Document No. 19, p. 38. 
Edigheji, O. (2004) 'The African State and Socio-Economic Development: An Institutional Perspective.' African Journal of Political Science 9(1), pp. 84-104.

Ekong, E. E. (1996). An Introduction to Rural Sociology. Jumak Publishers Ltd. Ibadan, Nigeria, pp. 57-61.

Federal Republic of Nigeria (2004) Nigeria: Demographic and Health Survey, 2003. National Population Commission, Federal Republic of Nigeria, April, 2004.

Gboyega, Alex (1980). "Community Participation and the Administration of Social Services in Nigeria" in Dele Olowu (ed.), The Administration of Social Services in Nigeria: The Challenge to Local Governments, University of Ife Press, Ile-Ife, Nigeria, pp. $120-128$.

Hardin, Garret (1968). The Tragedy of the Commons, Science 102.

Hatch, S. and Sherrot, R. (1973) "Positive Discrimination and the Distribution of Deprivations". Policy and Politics, Vol. 1, No 3.

Hickel, Walter J. (2002) The Crisis in the Commons: The Alaska Solution, Oakland: Institute for Contemporary Studies.

Hicks U. K. (1961): Development from Below: Local Government Finance in Developing Countries of the Commonwealth. London, Great Britain: Oxford University Press

Institute of Development Studies (IDS). 2001. From Consultation to Influence: Bringing Citizen Voice and Client Focus into Service Delivery. DFID Consultancy Report. Brighton, England: Institute of Development Studies.

Lewis, O. (1964) The Culture of Poverty", in Scientific American Vol. 215, No 4 Pp. 19-25

Mabogunje, A.L. (1999) "The Poverty Profile of Ijebu-Ode" Proceedings of address delivered at Ijebu-ode city Consultation held at the heritage hall of the Aafin of the Awujale, Oba Sikiru Adetona, Ogbagba II, on Monday, 22 March 1999.

Mamdani, M. (1996) Citizen and Subject: Contemporary Africa and the Legacy of Late Colonialism. Princeton, NJ: Princeton University Press.

Manuaka, Tony (2011) "Vision 2020: The Task Ahead". Tell Magazine, No. 31, August 8, 2011, p. 35.

McGaffey, J. 1992. "Initiatives from Below: Zaire's Other Path to Social and Economic Restructuring" in G. Hyden and M. Bratton (eds.) Governance and Politics in Africa. Boulder, Colorado: Lynne Rienner Publishers. pp. 243-262.

McGinnis, M. D. (1999). Polycentric Governance and Development: Readings from the Workshop in Political Theory and Policy Analysis. Ann Arbor: The University of Michigan Press.

Muzaali, P. (1987). Social Development, Rural Poverty and implication for fieldwork practice. Journal of Social Development in Africa, Vol. 2, No 1, pp. 175-187.

Narayan, D., R. Chambers, M. K. Shah, and P. Petesch (2001) Voices of the Poor: Crying out for Change, New York: Oxford University Press.

Nwafor, J. C., (2002). Church and State: The Nigerian Experience. Rutgers, The State University, New Jersey, USA.

Okotoni, M. O. and S. R. Akinola (1996). Governance of Nigeria's Villages and Cities: Case Studies of Ifetedo and Olode Communities. African Journal of Institution and Development (AJID) 2(1): 70-81.

Olomola, A. S. (2003) "Understanding Poverty in Nigeria: Highlights from the NISER Review of Nigerian Development." NISER Reel, Ibadan, Nos. 4 and 5, pp.3-9.

Olowu, Dele; Ayo, S. B. and Akande, Bola (1991) Local Institutions and National Development in Nigeria, Ile-Ife, Nigeria: Obafemi Awolowo University Press, Ile-Ife.

Olowu, C. A. B. and Akinola, S. R. (1995) "Urban Governance and Urban Poverty in Nigeria", in A. G. Onibokun and A. Faniran (eds.) Governance and Urban Poverty in Anglophone West Africa, Ibadan: Centre for African Settlement Studies and Development (CASSAD), Monograph Series 4, pp. 20 42.

Olowu, Dele. (1999). "Local Organizations and Development: The African Experience”, Polycentric Governance and Development: Readings from the Workshop in Political Theory and Policy Analysis. Ann Arbor: The University of Michigan Press, pp. 209-240.

(2006). "Towards a Local Governance and Poverty Reduction Programme at the African Development Bank.” In Millett, Karin, Olowu Dele \& Cameroon Robert (eds.). Local Governance and Poverty Reduction in Africa. ADB, IMF \& The World Bank. Published for the Joint Africa Institute, pp. 7-28.

Olowu, Dele and James Wunsch (2004). Local Governance in Africa: The Challenges of Democratic Decentralization. Boulder, Colorado: Lynne Rienner Publishers. 
Olson, Mancur (1965): The Logic of Collective Action: Public Goods and the Theory of Groups. Cambridge, MA: Harvard University Press.

Osei-Hwedies, K. (1993). Poverty, Targeted Programmes and Social Work Education in Africa, Institute of African Studies Research Review, New Series, Vol. 9. Nos 1, 2, University of Ghana, Legon.

Ostrom, E. (1990): Governing the Commons: the Evolution of Institutions for Collective Action. New York: Cambridge University Press.

(1992): Crafting Institutions for Self-Governance, Institute for Contemporary Studies, California, U.S.A. (2005) Understanding Institutional Diversity. Princeton and Oxford: Princeton University Press.

Ostrom, E. and Ostrom, V. (2003). Rethinking Institutional Analysis: Interviews with Vincent and Elinor Ostrom. Commemorating a Lifetime of Achievement, Mercatus Centre, George Mason University, USA, November 7, 2003.

Ostrom, V.(1971).Public Choice: A Different Approach to the Study of Public Administration Public Administration Review 31 (March-April), 201-216.

Ostrom, V. (1974) The Intellectual Crisis in American Public Administration $2^{\text {nd }}$ Edition, The University of Alabama press Tuscaloosa and London.

Ostrom, V., Feeny, D., \& Picht, H. (1988). Rethinking Institutional Analysis and Developments: Issues, Alternatives and Choices, San Francisco, California: ICS Press

Oyerinde, O. K. (2005). "Property Rights and Constitutional Order Among the Yoruba." Ph.D Thesis, Workshop in Political Theory and Policy Analysis, Indiana University, Bloomington, USA.

Ribot, Jesse (2000) Local Actors, Power and Accountability in African Decentralization: A Review of Issues. Geneva: United Nations Research Institute for Social Development.

Rowntree, S. (1901): Poverty: A Study in Town Life, London: Macmillan

Sawyer, A. (2005) Beyond Plunder: Toward Democratic Governance in Liberia. Boulder, Colorado: Lynne Rienner, Inc.

Sawyerr, Stella (2012). 'Economy: Nigeria’s Three 'Tribes.' Tell June 4, 2012, pp. 32-35. http://www.tellng.com/index.php?option=com_k2\&view=item\&id=1448:economy-nigeria'sthree-'tribes' (Accessed 07/06/2012).

Segalman, S. and A. Basu (1981): Poverty in America: The Welfare Dilemma, Contribution in Sociology, No. 39, London: Greenwood Press

Smock, Audrey. (1971). Ibo Politics: The Role of Ethnic Union in Eastern Nigeria. Cambridge, Massachusetts: Harvard University Press.

Soyombo, O. (1987): "Some issues in the conceptualisation and theory of urban poverty in Nigeria," in Makinwa, P. K and O. A. Ozo (eds.): The Urban Poor in Nigeria, pp. 1-13.

Tocqueville, A. (1966). Democracy in America, Vols.1\&2, Phillips Bradley, ed. New York: Vintage Books. First Published in 1835 and 1940.

The Comet, (Lagos) 06/11/2002, pp. 1, 2 \& 4.

UNDP (1999) An address delivered at the Ijebu-Ode city consultation held at the heritage hall of the Aafin of the Awujale, Oba Sikiru Adetona, Ogbagba II on Monday 22 March, 1999.

Wunsch, J. S. and Olowu, C. A. B. (eds.) (1995, 1999): The Failure of the Centralised State: Institutions and SelfGovernance in Africa, Boulder: Westview Press. 